Prof.dr.sci Sulejman Kendić ${ }^{1}$, Doc.dr.sci Adem Salihagić ${ }^{2}$

${ }^{1,2}$ Pedagoški fakultet Univerziteta u Bihaću

Odsjek za tjelesni i zdravstveni odgoj

\title{
Ultra violetno (UV) zračenje, kao negativni indeks zdravlja
}

\author{
Pregledni članak \\ (Review)
}

Sažetak

Zračenje koje nam dolazi sa Sunca uključuje vidljivo svjetlo, toplinu i UV radijaciju. UV zračenje pokriva područje valnih duljina 100-400 nm i dijeli sa u tri skupine UVA (315-400 nm), UVB (280-315 nm) i UVC (100-280 nm). Dok sunčeva svjetlost dolazi uatmosferu sva UVC i gotovo $90 \%$ UVB zračenja biva apsorbirano pomoću ozona, vodene pare, kisika i ugljičnog dioksida. Atmosfera ima malo utjecaja na UVA zrake, tako da UV zračenje koje dolazi na površinu zemlje ima veliku količinu UVA i manju količinu UVB zračenja.

Sunčevo zračenje je važan prirodni faktor zato jer stvara zemljinu klimu i ima značajan učinak na čitav okoliš. Ultraljubičasti dio sunčevog spektra ima vrlo važnu ulogu u mnogim procesima $u$ biosferi. Ima nekoliko korisnih učinaka, ali može biti $i$ vrlo štetno ukoliko prijeđe određenu "sigurnu" razinu.

Ako je iznos UV zračenja dovoljno visok, sposobnost samozaštite pojedinih bioloških jedinki nije dovoljna i jedinka može biti znatno oštećena. To se odnosi i na ljudski organizam, pogotovo na kožu i oči.

Da bi se izbjegla štetnost izloženosti UV zračenju, uvedena je veličina $U V$ indeks, koja bi trebala upozoravati ljude u stepen štetnosti UV zračenja i načinu poduzimanja određenih zaštitnih mjera.

UV zračenje u 21-om. stoljeću: naučiti se kontrolirati svoju izloženost sunčevom UV zračenju uporabom vlastitog iskustva $i$ profesionalnih preporuka; prilagodite svoje izlaganje sunčevom UV 
zračenju uvažavajući promjene vrijednosti UV indeksa; naučite poduzimati zaštitne mjere i podučavati mlade naraštaje da ih koriste; ako putujete u druga klimatska područja prilagodite svoje ponašanje na suncu na nove klimatske uvjete.

Prekomjerno izlaganje suncu $i$ njegovim štetnim ultraljubičastim (UV) zrakama godinama je poznato kao jedan od glavnih uzroka nastanka raka kože, pa i drugih bolesti. Oštećenju kože ultraljubičastim zrakama dodatno pridonose $i$ globalno zatopljenje, pojava ozonskih rupa i pojačano sunčevo zračenje.

Ključne riječi: UV zračenje, UV spektar, UV indeks.

\section{Uvod}

\section{Priroda ultraljubičastih zraka}

Sunce je glavni izvor UV zraka, a intenzitet zračenja ovisi o geografskoj širini, nadmorskoj visini, godišnjem dobu i dijelu dana, kao i o blizini snijega ili vode. Naime, bijeli pijesak, snijeg i voda reflektiraju do $85 \%$ UV zračenja. Solarno UV zračenje i vidljiva svjetlost predstavljaju energiju koju izvor (najčešće sunce) otpušta i transportira u obliku fotona. Oštećenja kože nastaju upravo zbog raspršivanja tih fotona $u$ sve slojeve kože. 10\% sunčeva spektra otpada na ultraljubičasto (UV) zračenje koje je biološki najaktivnije. $\mathrm{Na}$ vidljivi dio sunčevog spektra otpada $50 \%$, na infracrveni $40 \%$, a samo $10 \%$ otpada na UV zračenje. UV zračenje je dio spektra sunčeva zračenja koji se ne može zapaziti našim osjetilima, za razliku od svjetlosnog (vidljivog) i toplinskog (infracrvenog) zračenja koje čovjek može zamijetiti svojim osjetilima (svjetlost - očima, a toplinu - kožom).

\section{Spektar UV zračenja}

Zadnjih desetak godina znanstvenici upozoravaju i na oštećenje ozonskog sloja u atmosferi, čime sve više štetnih UV zraka dopire do površine Zemlje, tako da se povećava jačina sunčevog zračenja sa svim svojim negativnim posljedicama. Spektar UV 
zračenja obuhvaća valne duljine od 100 do $400 \mathrm{~nm}^{1}$ i sastoji se od tri skupine, i to: UV-C zrake (duljine kraće od $290 \mathrm{~nm}$ ) - predstavljaju najsnažnije zračenje unutar UV spektra i opasne su po život, ali ne dopiru do površine Zemlje, jer se u cijelosti filtriraju u ozonskom sloju tj. budu apsorbirane.

Zbog zabrinjavajućih oštećenja ozonskog sloja (stvaranje ozonskih rupa), zadnjih godina se opravdano pojavio strah od pojačanog propuštanja opasnih UV-C zraka. UV-B zrake (duljine 290-320 nm) - dopiru do površine Zemlje, a njihov štetni učinak na kožu oslabljen je slojem oblaka, prozorskim staklima, odjećom, tokom zime ili na višim geografskim širinama te ljeti rano ujutro i tokom kasnog poslijepodneva. Najjači učinak je ljeti upravo u podne. Izazivaju opekline na koži, ubrzavaju starenje kože, a smatraju se odgovornim i za nastanak karcinoma kože.

Kliničko iskustvo pokazalo je da imaju nepovoljan učinak na kožu od UV-A zraka zbog svoje veće energije. UV-A zrake (duljine 320-400 nm) - prodiru u dublje slojeve kože i prolaze kroz sloj oblaka, laganu odjeću i neobojeno staklo. Izazivaju tamnjenje kože bez nastanka opeklina. Prodiru dublje u kožu i odgovorne su za ubrzano starenje kože. Važno je napomenuti da UV-A zrake, za razliku od UVB zraka, prodiru kroz staklo i oblake. Ultraljubičaste zrake se ne mogu vidjeti golim okom.

Sunce je prirodni, glavni izvor UV zračenja. Takvom zračenju izložene su osobe koje rade na otvorenom (građevinski radnici, mornari, ribari...) te osobe za vrijeme godišnjeg odmora ili rekreacijskih aktivnosti. Štetnom učinku UV zračenja izložena su i djeca za vrijeme ljeta, a bez odgovarajuće foto-protekcije, što utječe na razvoj foto-oštećenja kože kasnije u životu. Osim sunca, danas postoje i umjetni izvori UV zraka: solariji koji se koriste u kozmetičke svrhe te foto-terapija u dermatološkim klinikama, ali samo u terapijske svrhe i samo kod određenih dermatologa.

${ }^{1} \mathrm{~nm}=$ nanometar $\left(1 \mathrm{~nm}=10^{-9} \mathrm{~m}\right)$ 


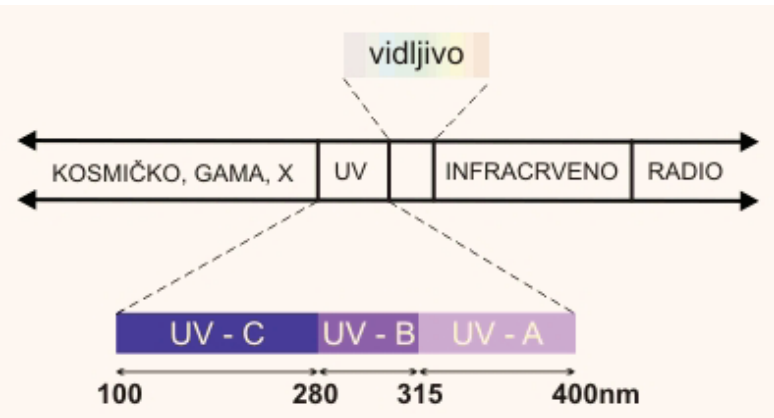

Slika 1. Elektromagnetski spektar sunčevog zračenja

UV zračenje se može mjeriti kao ozračenje ili iradijancija snaga pristigla na jediničnu površinu - $\mathrm{u}$ jedinicama ${ }^{2} \mathrm{~W} / \mathrm{m}^{2}$, ili kao ozračenost (radijativna izloženost) ili doza - energija pristigla na jediničnu površinu u specifičnom vremenskom intervalu - u jedinicama ${ }^{3} \mathrm{~J} / \mathrm{m}^{2}$.

\section{Najvažniji faktori koji utječu na UV zračenje}

\section{Atmosferski ozon}

UV zračenje je apsorbirano i raspršeno u atmosferi. UV-C zračenje je potpuno apsorbirano u gornjoj atmosferi na molekulama kisika i ozona. Većinski dio UV-B zračenja je apsorbiran u stratosferi na molekularni ozon a samo nekoliko postotaka dolazi do zemljine površine. Zbog toga je na površini zemlje sunčevo UV zračenje sastavljeno od velikog iznosa UV-A zračenja i vrlo malog iznosa UVB zračenja. Poznato je da je UV-B zračenje biološki vrlo štetno. UVA je manje štetno, ima mogućnost stvaranja tena na ljudskoj koži. S obzirom da je ozon glavni apsorber UV-B zračenja, intenzitet UV-B zračenja na zemljinoj površini zavisi o ukupnom iznosu ozona $u$ atmosferi i nadalje o debljini ozonskog sloja.

\footnotetext{
${ }^{2} \mathrm{~W}$-vat, svjetlosna veličina (tok isijavanja)

${ }^{3} \mathrm{~J}$ (džul), jedinica za energiju. 


\section{Visina sunca}

Visina sunca je ugao između horizonta i smjera prema suncu. Solarni zenitni ugao (Solar Zenith Angle - SZA) se često upotrebljava umjesto visine sunca: to je ugao između zenita i smjera sunca. Za velike visine sunca UV zračenje je puno intenzivnije, jer zrake sunca prolaze kraći put kroz atmosferu i zato prolaze kroz manje područje apsorpcijskih tvari. S obzirom da UV zračenje ovisi o visini sunca, ono se mijenja s geografskom širinom, dobom godine i dobom dana. Zato je UV zračenje najjače u tropskom području, ljeti, u vrijeme podneva.

\section{Nadmorska visina}

UV iradijancija se povećava s nadmorskom visinom zato jer je manje apsorpcijskih tvari $\mathrm{u}$ atmosferi iznad dane visine. Mjerenja pokazuju da UV zračenje poraste za $6-8 \%$ za porast nadmorske visine od $1000 \mathrm{~m}$.

\section{Atmosfersko raspršenje}

$\mathrm{Na}$ zemljinoj površini se sunčevo zračenje sastoji od izravne i raspršene (difuzne) komponente. Solarno zračenje je raspršeno na molekulama zraka i ostalim česticama kao što su aerosol i vodene kapljice. Izravna komponenta se sastoji od zraka sunca koje su prošle izravno kroz atmosferu bez raspršenja ili apsorpcije. Difuzna komponenta se sastoji od zraka koje su bile raspršene barem jednom prije nego su stigle na tlo. Raspršenje zavisi o valnoj duljini.

\section{Oblaci i atmosferska mutnoća}

UV ozračenje je jače kada je nebo vedro, bez oblaka. Oblaci generalno smanjuju UV zračenje, ali slabljenje na oblacima ovisi i o debljini oblaka i o tipu oblaka (optička debljina oblaka). Tanki ili raskidani oblaci imaju samo mali učinak UV na tlu. U određenim uvjetima i za kratke vremenske periode mala naoblaka može na nekim mjestima čak i povećati UV iradijanciju u usporedbi sa potpuno vedrim nebom. U uvjetima atmosferske mutnoće UV zračenje je 
apsorbirano i raspršeno na vodenim česticama i aerosolu i to dovodi do smanjena UV zračenja.

\section{Refleksija na tlu}

Dio UV zračenja pristiglog do tla je apsorbiran na zemljinoj površini, a dio je odbijen (reflektiran) natrag prema svemiru. Iznos reflektiranog zračenja ovisi o svojstvima površine. Većina prirodnih površina kao što su trava, zemlja i voda reflektiraju manje od $10 \%$ pristiglog UV zračenja. Svježi snijeg može reflektirati i do $80 \%$ pristiglog UV zračenja.

Postoje tri vrste bliještanja:

1. direktno (potječe od samog izvora svjetla)

2. indirektno (nastaje refleksijom svjetla od različitih površina $u$ prostoriji)

3. kontrastno (nastaje zbog prevelike razlike u sjajnosti dijelova vidnog polja.

U proljeće kod vedrog neba refleksija na snijegu može povećati UV iradijanciju na nagnutim površinama čak do ljetnih vrijednosti. To je značajno na višim nadmorskim visinama i u višim geografskim širinama.

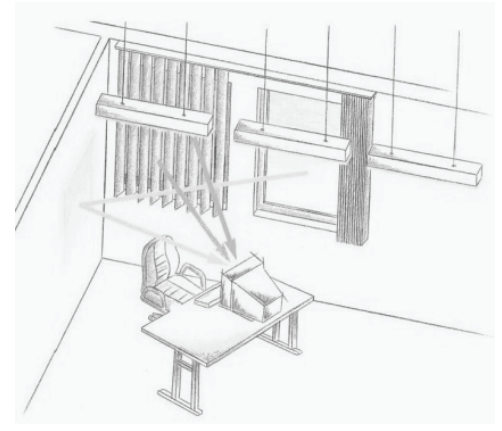

Slika 2. Direktno i indirektno blještanje

Pijesak može reflektirati oko $25 \%$ UV zračenja i povećati UV izloženost na plaži. Do $95 \%$ UV zračenja može prodrijeti u vodu, a oko 50\% može prodrijeti čak do $3 \mathrm{~m}$ dubine (u čistoj oceanskoj vodi). 


\section{UV indeks}

UV indeks je povezan $\mathrm{s}$ dobro poznatim eritemalnim (crvenilom) učincima sunčevog UV zračenja na ljudsku kožu, a njegova definicija je standardizirana i publicirana kao zajednička preporuka Svjetske zdravstvene organizacije (World Health Organization - WHO), Svjetske meteorološke organizacije (World Meteorological Organization - WMO), Programa Ujedinjenih naroda za okoliš (United Nations Environment Programme - UNEP) i Međunarodne komisije za neionizirajuće zračenje (International Commission on Non-Ionizing Radiation - ICNIRP).

\section{UV indeks:}

- je jednica mjere UV razine, relevantna učincima na ljudskoj koži (UV izazvan eritem)

- je definiran kao djelovanje ozračenosti dobiven integriranjem spektralne ozračenosti pomnožene težinskom funkcijom CIE (1987) po valnim duljinama od 290 do $400 \mathrm{~nm}$

- je izražen numerički, kao ekvivalent vremenski otežanog i osrednjeg učinkovitog zračenja $\left(\mathrm{W} / \mathrm{m}^{2}\right)$ pomnoženog sa 40

\section{Vrijednosti UV indeksa}

\section{Kategorije UV indeksa}

\begin{tabular}{|l|l|l|}
\hline & $\begin{array}{l}\text { Vrijednosti UV indeksa 1 i 2 označuju nisku } \\
\text { opasnost od UV zračenja. Većina ljudi može biti } \\
\text { izložena suncu i više od sat vremena, a da ne dobije } \\
\text { opekline. Za zaštitu se preporučuje korištenje } \\
\text { sunčanih naočala. Za ljude koji imaju vrlo osjetljivu } \\
\text { kožu i za novorođenčad nalaže se stalan oprez. } \\
\text { Ukoliko moraju boraviti na suncu sredinom dana, } \\
\text { dobro je upotrijebiti sunčane naočale i zaštitnu } \\
\text { kremu. }\end{array}$ & $\begin{array}{l}\text { Zbog odbijenog zračenja } \\
\text { posebno oprezni moraju } \\
\text { biti skijaši, planinari, } \\
\text { plivači i jedriličari. }\end{array}$ \\
\hline $\begin{array}{l}\text { Vrijednosti UV indeksa 3, 4, i } 5 \text { označuju umjerenu } \\
\text { opasnost od UV zračenja. Za zaštitu se preporuča } \\
\text { nošenje šešira sa širokim obodom, sunčanih naočala, } \\
\text { te korištenje zaštitnih krema. } \\
\text { Ljudi s osjetljivom kožom bi, osim tih mjera, trebali } \\
\text { nositi i odjeću s dugim rukavima, jer mogu dobiti } \\
\text { opekline već za 20 minuta. }\end{array}$ & $\begin{array}{l}\text { Dobro je pratiti vlastitu } \\
\text { sjenu. Što je ona kraća, } \\
\text { veća je opasnost od UV } \\
\text { zračenja. }\end{array}$ \\
\hline UND
\end{tabular}




\begin{tabular}{|c|c|c|}
\hline UV UV & $\begin{array}{l}\text { Vrijednosti UV indeksa } 6 \text { i } 7 \text { označuju već visoku } \\
\text { opasnost od UV zračenja. Za zaštitu se preporučuje } \\
\text { nošenje šešira sa širokim obodom, sunčanih naočala, } \\
\text { odjeće s dugim rukavima, te korištenje zaštitnih } \\
\text { krema. Ljudi s osjetljivom kožom i mala djeca } \\
\text { mogu dobiti opekline za manje od } 20 \text { minuta. Za } \\
\text { njih je bolje da se ne izlažu suncu u doba dana } \\
\text { između } 11 \text { i } 16 \text { sati. }\end{array}$ & $\begin{array}{l}\text { Prilikom boravka na } \\
\text { otvorenom potrebno je } \\
\text { zaštititi nos, uši i usnice }\end{array}$ \\
\hline UV & $\begin{array}{l}\text { Vrijednosti UV indeksa } 8,9 \text { i } 10 \text { označuju vrlo } \\
\text { visoku opasnost od UV zračenja. Za zaštitu se } \\
\text { preporučuje nošenje šešira sa širokim obodom, } \\
\text { sunčanih naočala } i \text { odjeće s dugih rukavima, te } \\
\text { korištenje zaštitnih krema. Maksimalno valja } \\
\text { smanjiti boravak na suncu u doba dana između } 11 \mathrm{i} \\
16 \text { sati. Djeca mogu dobiti opekline za manje od } 10 \\
\text { minuta. }\end{array}$ & $\begin{array}{l}\text { UV zračenje može } \\
\text { prodrijeti kroz odjeću od } \\
\text { rijetkog tkanja i naštetiti } \\
\text { koži. }\end{array}$ \\
\hline & $\begin{array}{l}\text { Vrijednosti UV indeksa } 11 \text { i iznad označuju } \\
\text { ekstremnu opasnost od UV zračenja. Za zaštitu se } \\
\text { preporučuje boravak u zatvorenom prostoru u doba } \\
\text { dana između } 11 \text { i } 16 \text { sati. Ukoliko je izlazak } \\
\text { neizbježan, potrebno je nositi šešir sa širokim } \\
\text { obodom, sunčane naočale i odjeću dugih rukava od } \\
\text { gustog tkanja, koristiti zaštitne kreme i izbjegavati } \\
\text { boravak na izravnom suncu. Djeca mogu dobiti } \\
\text { opekline za manje od } 5 \text { minuta. }\end{array}$ & $\begin{array}{l}\text { Film ili knjiga uz } \\
\text { osvježenje u kući puno su } \\
\text { zdraviji od ležanja na } \\
\text { plaži. }\end{array}$ \\
\hline
\end{tabular}

- Ne smije se zaboraviti na odbijeno (reflekltirano) UV zračenje, pa posebno oprezni trebaju biti skijaši $i$ ljudi koji borave $u$ planinama, kao i oni na moru (plivači, jedriličari) koji trebaju posebno zaštititi područja ispod brade i nosa.

- Dobro je pratiti vlastitu sjenu. Što je ona kraća, postoji veća opasnost od UV zračenja.

- Ukoliko se radi ili boravi na otvorenom svakako zaštitite vrlo osjetljiva područja kao što su nos, vrhovi ušiju i usnice.

- Svakako je dobro potražiti sjenu, ali treba biti svjestan da voda, pijesak, beton, stijene, refleksijom UV zračenja mogu povećati nivo UV zračenja $i$ u sjeni pa je $i$ u sjeni potrebna zaštita. Dobro je koristiti odjeću od gusto tkanog materijala, jer UV zrake mogu prodijeti kroz rijetku tkaninu.

- Film ili dobra knjiga uz osvježenja u zatvorenom prostoru svakako su puno zdravije rješenje od ležanja na plaži. 
Tabela 1. Približna procjena UV indeksa za podne, vedri dan, sredina mjeseca

\begin{tabular}{|c|c|c|c|c|c|c|c|c|c|c|c|}
\hline \multicolumn{12}{|c|}{ Mjeseci } \\
\hline $\mathrm{I}$ & II & III & IV & V & VI & VII & VIII & IX & $X$ & XI & XII \\
\hline \multicolumn{12}{|c|}{ UV indeks } \\
\hline 1 & 2 & 4 & 6 & 8 & 9 & 10 & 9 & 6 & 4 & 2 & 1 \\
\hline
\end{tabular}

Tabela 2. Približna procjena UV indeksa za podne, vedri dan, juli mjesec

Sati
\begin{tabular}{|l|l|l|l|l|l|l|l|l|l|l|l|}
\hline 7 & 8 & 9 & 10 & 11 & 12 & 13 & 14 & 15 & 16 & 17 & 18 \\
\hline UV indeks \\
\hline 1 & 3 & 5 & 7 & 9 & 10 & 9 & 7 & 5 & 3 & 1 & 0 \\
\hline
\end{tabular}

\section{Preporuke}

\section{Izloženost suncu}

Koža i oči su ljudski organi koji su najviše izloženi sunčevom ultraljubičastom zračenju. Iako su kosa i nokti također dosta izloženi, oni su manje važni s medicinskog stanovišta. Izloženost UV zračenju može rezultirati akutnim i kroničnim učincima na zdravlje kože (eritem, starenje kože, rak kože) očiju (fotokeratitis, snježno sljepilo, katarakt) i imunološki sistem. Dok UV-B zračenje uglavnom uzrokuje eritem i različite vrste raka kože, UV-A zračenje ima izrazit učinak na potkožno tkivo i može promijeniti strukturu kolagena i elastičnih vlakana što ubrzavaju starenje kože. Važno je naglasiti da koža ima kapacitet prilagođavanja UV zračenju proizvodnjom melanina (tena) koji štiti od UV izloženosti, dok ljudsko oko takav kapacitet nema.

Štetni učinci UV zračenja na tipove kože

Štetni učinci UV zračenja ovise ne samo o primljenoj UV dozi već i o osjetljivosti pojedinaca. Ljudska koža je često podijeljena na četiri glavne grupe prema sposobnosti kože da se razvije pigmentacija. 
Fototip 1 - odnosi se na vrlo svijetlu kožu, pjege, crvenu ili plavu kosu te plave ili zelene oči. Ovaj tip kože nikad ne potamni i uvijek izgori. Zbog smanjene pigmentacije, razina otpornosti na opekline izrazito je niska, pa koža počinje reagirati jačim crvenilom već desetak minuta nakon izlaganja suncu. Ovakav fototip kože ima oko $2 \%$ populacije

Fototip 2 - označava svijetlu put sklonu razvoju pjega ljeti i plavu kosu. Pigmentacija je vrlo slaba, pa je koža sklona opeklinama. Bez odgovarajuće zaštite opekline se javljaju već nakon deset do dvadeset minuta izlaganja suncu. Preporučeno vrijeme izlaganja suncu bez zaštitnih sredstava je do dvadeset minuta, a inače bi trebali koristiti zaštitni faktor 15 . Ovaj tip kože ima oko $12 \%$ stanovništva.

Fototip 3 - srednje svijetla koža, tamnija ili tamna kosa i svijetlosmeđe oči. Iako je zbog dobre pigmentacije ovaj tip kože manje osjetljiv na opekline, bez zaštite može zadobiti opekline nakon pola sata izlaganja suncu. Ovo je najčešći tip kože i prisutan je kod oko $78 \%$ populacije.

Fototip 4 - označava tamni fototip (mediteranski tip), tj. tamniju kožu (maslinasta put) i kosu. Zbog jačeg pigmenta ovaj tip kože razvija opekline nakon 45 minuta izlaganja suncu. Savjetuje se korištenje krema s faktorom zaštite 6 . Ima ga $8 \%$ populacije.

Minimalna eritemalna doza (Minimal Eritemal Dose - MED), je veličina upotrijebljena za opis eritemalnog potencijala UV zračenja. 1 MED je definiran kao djelotvornost UV doza koja uzrokuje percepcijsko crvenilo na do tada neizloženoj koži. S obzirom da ljudski organizmi nisu jednako osjetljivi na UV zračenje, zbog različitih samozaštitnih sposobnosti njihove kože (pigmentacije), 1 MED varira među europskom populacijom u rasponu od 200 do 500 $\mathrm{J} / \mathrm{m}^{2}$. 
Tabela 3. Tip kože, vrijeme izlaganja suncu, preporučene kreme sa zaštitnim faktorom

\begin{tabular}{|l|l|l|}
\hline Tip kože & $\begin{array}{l}\text { Vrijeme izlaganja } \\
\text { suncu bez zaštitnih } \\
\text { sredstava od 10-16 } \\
\text { sati }\end{array}$ & $\begin{array}{l}\text { Preporučeni } \\
\text { zaštitni faktor }\end{array} \quad$ UV \\
\hline Vrlo svijetla put & 5 do 10 minuta & $20-30$ \\
\hline Svijetla put & 10 do 20 minuta & $12-15$ \\
\hline Tamna put & 20 do 30 minuta & $8-10$ \\
\hline Vrlo tamna put & $30-40$ minuta & $4-6$ \\
\hline
\end{tabular}

Zaštita kože

Koža se najbolje štiti odjećom. Šešir, košulja i hlače pružaju najbolju zaštitu. Proizvođači bi vidljivo trebali označiti odjeću koja propušta UV zračenje. Dijelovi kože koji nisu zaštićeni odjećom trebaju se zaštititi zaštitnom kremom koja sadrži UV-B i UV-A filtere. Tokom prvog izlaganja suncu preporučuje se zaštitna krema sa visokim zaštitnim faktorom (Sun Protected Factor - SPF), oko 30. Naročitu brigu treba posvetiti novorođenčadi i maloj djeci. Treba naglasiti da zaštitini učinak zaštitnih krema ovisi ne samo o kvaliteti krema, već i o ispravnoj primjeni krema. Preporuka je da se zaštitna krema sa zaštitinim faktorom najmanje 15 primjenjuje svaka 2 sata da bi bila djelotvorna. Potrebna je dobra primjena prije izlaganja suncu i potrebna je ponovna primjena nakon kupanja. Pravilna primjena zaštitne kreme može biti dobra zaštita od opeklina, raka kože i starenja kože.

Tablica 3. Definicija temeljnih fototipova kože za europsku populaciju

\begin{tabular}{|l|l|l|l|l|}
\hline Fototip kože & I & II & III & IV \\
\hline $\begin{array}{l}\text { Stvaranje } \\
\text { tena }\end{array}$ & nikad & katkad & uvijek & uvijek \\
\hline $\begin{array}{l}\text { Opekline od } \\
\text { sunca }\end{array}$ & uvijek & katkad & rijetko & nikad \\
\hline Boja kose & crvena & plava & smeđa & crna \\
\hline Boja očiju & plava & plava $/$ zelena & siva $/ \mathrm{smeđa}$ & smeđa \\
\hline $\mathbf{1 ~ M E D ~}$ & $200 \mathrm{~J} / \mathrm{m}^{2}$ & $250 \mathrm{~J} / \mathrm{m}^{2}$ & $350 \mathrm{~J} / \mathrm{m}^{2}$ & $450 \mathrm{~J} / \mathrm{m}^{2}$ \\
\hline
\end{tabular}


Zaštitini faktor (SPF) naznačen na pakiranju označava koliko je proizvod djelotvoran. Više vrijednosti SPF-a - bolja djelotvornost zaštitne kreme. U svim slučajevima zaštitne kreme se ne bi smjele upotrebljavati zbog produženja vremena izloženosti suncu, već bi se češće trebale koristiti da se smanje štetni učinci prilikom neizbježne izloženosti suncu. To je razlog zašto se kreme trebaju upotrebljavati na dijelove kože koji nisu pokriveni odjećom, pogotovo osjetljivaisturena područja kao što su nos, uši, vrat, leđa i gornja strana stopala. Za odabir najpogodnijeg zaštitinog faktora može okvirno poslužiti tablica 4 u kojoj su naznačene SPF vrijednosti za različiti tip kože i različiti UV indeks. Upotreba nekih lijekova, protuupalnih agensa, antimikrobskih produkata, parfema, desodoransa može dovesti do reakcija na koži ili očima koje mogu izmijeniti djelotvornost zaštitnih mjera. Takve fotoosjetljive reakcije mogu rezultirati u stvaranju eritema i kod nižih UV doza.

Tabela 4. Preporučeni SPF faktori za različit fototip kože i različite vrijednosti UV indeksa

\begin{tabular}{|l|l|l|l|l|}
\hline UV indeks & Fototip kože & \multicolumn{4}{l|}{} \\
\hline & I & II & III & IV \\
\hline $1-3$ & 15 & 12 & 9 & 6 \\
\hline $4-6$ & 30 & 25 & 15 & 12 \\
\hline $7-9$ & 50 & 40 & 30 & 20 \\
\hline 10 i više & 60 & 50 & 40 & 30 \\
\hline
\end{tabular}

\section{Zaštita očiju}

Oči se trebaju zaštititi sunčanim naočalama koje sadrže UV-B i UV-A filtere. Proizvođači bi trebali stavljati kategoriju zaštite stakala od vidljivog i UV svjetla na prednju stranu naočala. Za opću upotrebu se preporučuje kategorija 3 , a za aktivnosti visokog rizika kao što su planinarenje ili jedrenje preporuča se kategorija 4. Nadalje, zbog bočne izloženosti preporučuje se upotraba naočala s bočnom zaštitom. Takav savjet je posebno važan za djecu jer je transmisivnost UV zračenja kroz dječije oči puno veća nego kod odraslih - dječija retina 
je slabije zaštićena. Načelo je da se sunčane naočale bez UV zaštitnih filtera ne koriste.

\section{Zaključak}

1. Sadašnji trendovi i ponašanje ozonskog sloja su jako uvjetovani radijativnim, kemijskim i dinamičkim procesima u stratosferi. Značaj tih procesa može biti povećan ljudskim aktivnostima (npr. "učinak staklenika") i rezultirati u većim varijacijama ozonskog sloja i UV-B zračenja. Očekivana obnova ozonskog sloja sredinom 21. stoljeća bi trebala omogućiti stabilizaciju UV-B zračenja u slijedećim desetljećima. Negativni učinci na zdravlje ljudi mogli bi se eliminirati profesionalnom sviješću javnosti utemeljenoj na pravodobnim informacijama o UV indeksu.

2. U svakom slučaju, 21. stoljeće donosi izazov za povećanu osobnu kontrolu izloženosti UV zračenju i poduzimanju zaštitnih mjera, barem za velik dio fotoosjetljivog dijela ljudske populacije.

\section{Faktori u okolišsu koji utječu na količinu UV zračenja}

- Položaj sunca - što je sunce više na nebu, to je veći nivo UV zračenja. Ta količina zračenja varira s obzirom na dio dana $\mathrm{i}$ doba godine. Najviši nivo postiže kada je sunce direktno iznad nas, oko podne, za vrijeme ljetnih mjeseci.

- Geografska širina - što smo bliže ekvatoru, to je viša količina UV zračenja.

- Sloj oblaka - kada je nebo vedro, veća je količina UV zračenja. Čak i kada je oblačno UV zračenje može biti visoko, jer ga raspršuju molekule vode i fine čestice u atmosferi

- Nadmorska visina - što je viša nadmorska visina, tanji je sloj atmosfere koji filtrira UV zračenje. Svakih 1000 metara u visinu, raste nivo zračenja za 10 do $12 \%$.

- Ozon - ozon upija dio UV zračenja koje bi inače došlo na površinu zemlje. Količina ozona varira kroz godinu, pa čak i tokom dana. 
- Odsjaj površine - UV zračenje može biti reflektirano ili raspršeno, ovisno o vrsti površine, npr. snijeg može reflektirati oko $80 \%$ UV zračenja, suha plaža oko $15 \%$ i more oko $25 \%$.

\section{Mjere opreza}

- Ograničite vrijeme boravka na podnevnom suncu - UV zračnje je najjače između 10 i 16 sati. Izbjegavajte boravak na suncu u ovo doba dana.

- Paziti na UV index - ovo je važan podatak koji omogućava planiranje aktivnosti na otvorenom, a s ciljem sprečavanja štetnog izlaganja sunčevim zrakama. Uvijek prilagoditi faktor svoje zaštite trenutnome UV indeksu.

- Mudro koristiti hlad - Potražiti hladovinu kada je UV zračenje najintenzivnije, ali imajte na umu da hlad od stabla, suncobrana ili tende ne pruža potpunu zaštitu od sunca. Zapamtite važno pravilo: "Ukoliko ne vidite svoju sjenu (što znači da je podne) potražite hladovinu".

- Nosite zaštitnu odjeću - šešir sa širokim obodom pruža dobru zaštitu za oči, uši, lice i zadnji dio vrata. Sunčane naočale koje pružaju 99 ili 100 postotnu zaštitu od UVA ili UVB zračenja uvelike će smanjiti oštećenje oka od izlaganja suncu. Prozračna i lagana odjeća pružit će dodatnu zaštitu.

- Koristiti kreme za sunčanje. Nanijeti zaštitu protiv sunca zaštitnog faktora 15 ili više, te je obnavljajte svaka dva sata ili nakon fizičkog napora, plivanja, igre ili rekreacije na otvorenom.

\section{Djeca su najosjetljivija}

Djeca su osjetljivija na utjecaje okoliša od odraslih. Mnoge vitalne funkcije, poput imuniteta, nisu potpununo razvijena, te neprimjereni okoliš može imati loš utjecaj na njihov razvoj.

Mjere opreza:

- Neka djeca borave u hladu kada je god to moguće. 


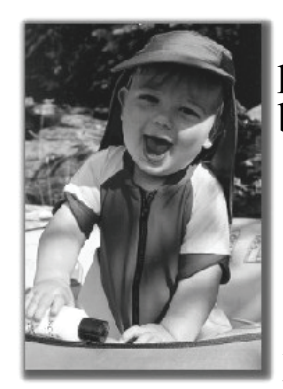

- Obući djecu u komotnu, pamučnu odjeću, koja prekriva što veću površinu tijela, ali tako da im ne bude pretoplo.

- Male bebe, mlađe od 6 mjeseci, potrebno je u svakom slučaju skloniti sa direktnog utjecaja sunčevog zračenja. Tako malena djeca nisu $u$ mogućnosti pomaknuti se u hlad ili nam reći da im je pretoplo, te ih je stoga sigurnije držati u hladovini.

\section{Tamna strana sunčanja}

Zašto koža stari?

Dva su razloga za starenje kože. Prvo, prirodno starenje kože je neizbježno i povezano je s kronološkim starenjem, odnosno unutarnjim biološkim satom. To je relativno spor proces pa ako pokušamo izbjeći određene štetne činioce, možemo odgoditi pojavu znakova starenja za što kasniju životnu dob. Drugi, i najčešći razlog starenja kože je učinak vanjskih faktora, prvenstveno UV zraka, ali svakako moramo istaknuti da i dim cigarete i alkohol imaju određeni učinak. Navedeni vanjski faktori samo ubrzavaju proces starenja, dovodeći do pojave svih prijevremenih znakova starenja kože, koji bi se inače mogli odgoditi za kasniju životnu dob, ako bi se pridržavali pravila zdravog ponašanja. Dakle, poznato je da UV zračenje predstavlja primarni uzrok većine znakova prijevremenog starenja kože, prvenstveno bora, suhe kože i neravnomjerne pigmentacije. Takve promjene nazivamo foto-starenje kože (engl. photo-ageing). Naime, UVA i UVB zrake prodiru u kožu i oštećuju strukturu kolagena i elastičnih vlakana, uzrokujući gubitak gipkosti i elastičnosti kože te sposobnosti vezanja vlage, uz postupno razvijanje bora. Zbog takvih promjena, dermis postaje sve tanji, a kapilare sve vidljivije.

\section{Prekomjerno sunčanje}

Prekomjerno sunčanje može izazvati:

Zloćudne promjene - oštećenja na razini DNA na koži mogu razviti prekanceroze i karcinomi kože. Najčešći karcinomi kože (tzv. 
nemelanomski karcinomi) su bazocelularni i planocelularni karcinomi, koji u više od $90 \%$ slučajeva nastaju na suncu izloženoj koži. Karcinom kože klinički karakterizira pojava "ranice koja dugo traje i koja ne cijeli". Valja naglasiti da je utvrđena čvrsta povezanost između učinka UV zračenja i nastanka malignog melanoma, osobito u osoba svijetle puti s brojnim pigmentiranim lezijama (oštećenjima). Treba istaknuti i opasnost tzv. rekreativnog sunčanja, što se odnosi na intenzivno izlaganje suncu u kratkom vremenskom razdoblju, najčešće u vrijeme kratkog godišnjeg odmora s ciljem da se što brže postigne "tamna boja".

Reakcije kože ili pogoršanje postojećih bolesti - Osim navedenoga, neki ljudi će prilikom izlaganja suncu na koži razviti alergijske ili toksične reakcije u obliku crvenila, papula, svrbeža, a katkada i mjehurića. Takve promjene mogu nastati kao posljedica upotrebe kozmetičkih sredstava, parfema, biljnih preparata (ili $\mathrm{u}$ kontaktu s biljkama), lokalnih medicinskih pripravaka, kao i tokom peroralne terapije (najčešće antibioticima). Određene kožne bolesti mogu se na suncu pogoršati, što uključuje virusne bolesti (Herpes simplex) i neke druge kožne bolesti (npr. Lupus erythematosus). Takve promjene nastaju zbog potiskivanja (supresije) imunološkog sistema, koja tokom dužeg vremenskog razdoblja ima ulogu i u nastanku karcinoma kože.

Kako izbjeći oštećenje kože?

Da bi se izbjeglo štetno djelovanje UV zraka na kožu valja se pridržavati sljedećih mjera:

- izbjegavati izlaganje suncu u razdoblju između 10 i 17 sati,

- nositi zaštitnu odjeću, kapu ili šešir širokog oboda,

- nositi zaštitne naočale koje pružaju $100 \%$ UV zaštitu,

- upotrebljavati kreme s visokim zaštitnim faktorom (SPF), višim od 15 (nanijeti ih najmanje pola sata prije izlaganja suncu i ponovljeno nanositi svaka 2 sata),

- djecu mlađu od 6 mjeseci ne izlagati suncu,

- pratiti UVI - UV indeks.

Oštećenje kože počinje prvim izlaganjem suncu i kumulativnog je karaktera, stoga nikad nije dovoljno rano za zaštitu. 
Otkako je početkom sedamdesetih godina preplanulost postala statusni simbol, znak zdrava i lijepa tijela, medicinski stručnjaci redovito upozoravaju na opasnosti koje donosi uživanje u suncu. No, unatoč stalnim upozorenjima, mnogi se ljudi i dalje nekontrolirano izlažu suncu, što dolazi do nepopravljivih oštećenja na koži

Osim štetnih utjecaja sunca na našu kožu, valja spomenuti i njegove pozitivne utjecaje na organizam. Da nema sunca, ne bi bilo ni života na zemlji. Sunce je, dakle, izvor života i energije za sva živa bića. Pod utjecajem sunčevih zraka u našem organizmu stvara se nama nužan D vitamin. UV zračenje se kao umjetni izvor zračenja koristi u terapiji (fototerapija) različitih kožnih bolesti, primjerice psorijaze, atopijskog dermatitisa, kontaktnog alergijskog dermatitisa, a u kombinaciji s nekim lijekovima, za liječenje određenih tipova limfoma kože.

\section{Negativni utjecaji UZV zračenja koji se kumuliraju}

Akutno oštećenje kože od UV zračenja manifestira se pojavom crvenila različita intenziteta (opekline), a kronična oštećenja odnose se na kumulativno oštećenje, koje se kasnije manifestira prijevremenim starenjem kože, pojavom prekanceroza i karcinoma, odnosno melanoma kože. Od svih vrsta zračenja koja iz sunca isijavaju, na oko najopasnije djeluje UV zračenje. Akutna oštećenja na očima očituju se razvojem fotokeratitisa (upale rožnice) i fotokonjunktivitisa (upale očne spojnice). Dugotrajno izlaganje UV zračenju može dovesti i do katarakte (zamućenja očne leće), pterygiuma (bjelkastih naslaga na bjeloočnici) i tumora kože vjeđa. Studije su pokazale da izlaganje očiju UV zračenju više od četiri sata dnevno dovodi do tri puta veće opasnosti od razvoja katarakte $u$ usporedbi s osobama koje nose zaštitne naočale s UV filtrima. Zbog toga, ali i činjenice da se zbog promjena u zaštitnom ozonskom sloju intenzitet UV zraka povećava, a time i njihova štetnost, sunčane naočale treba nositi tokom cijele godine, a važno je da ih nose i odrasli i djeca. 


\section{Kako odabrati zaštitno sredstvo}

Vrlo je važno znati odabrati odgovarajuće zaštitno sredstvo, tj. kremu za zaštitu od sunca koja štiti od štetnog djelovanja UV zraka. Ambalaža zaštitnih sredstava ima oznaku SPF, što je kratica za Solar Protection Factor, a znači da takav proizvod sadrži zaštitu od UV zračenja i daje nam podatak koliko prosječno možemo ostati na suncu uz primjenu kreme za zaštitu od sunca, a da ne dobijemo opekline. Što je sposobnost kreme za zaštitu od sunca za apsorpciju UV zraka veća, veći je i faktor zaštite. SPF u najvećoj mjeri označava zaštitu od UVB zraka, a neki njezini sastojci blokiraju i UVA zrake.

Među sastojke koji upijaju i UVA zrake ubrajamo avobenzon, oktokrilen, titan-dioksid, cinkov oksid i meroxyl SX. Bez obzira na broj SPF, krema za zaštitu od sunca mora se na kožu nanijeti pola sata prije izlaganja i iznova nanositi svakih sat do dva, jer zaštitno sredstvo nestaje znojenjem ili kupanjem, a i općenito nakon izlaganja sunčevoj svjetlosti aktivni sastojci se počinju raspadati. Koji ćemo zaštitni faktor upotrijebiti, ovisi i o planiranom razdoblju boravka na suncu. Ako se radi na otvorenom i nije u mogućnosti izbjegavati izloženost sunčevim zrakama od 10 do 16 sati, svakako treba upotrijebiti najjači zaštitni faktor. Neki proizvodi nose natpis koji potvrđuje vodootpornost, no to se odnosi na vrijeme od 40 do 80 minuta. Stoga se savjetuje nanijeti kremu za zaštitu od sunca nakon svakog kupanja. U svijetu se uvažava jedino kriterij vodootpornosti američke Food and Drug Administration (FDA), po kojem je preparat vodootporan ako nakon dva kupanja (plivanja) od 20 minuta na koži ostane 50 posto nanesenog preparata.

\section{Literatura:}

1. B. Vujičić i S. Djurović: Astrofizika sa astronomijom PMF, Novi Sad (1995)

2. K.N. Liou: In Introduction to Atmospheric Radiation Academic Press, Inc. New York (1980)

3. R.M. Goody: Atmospheric Radiation (I Theoretical Basis) Clarendon Press, Oxford (1964)

4. K.L. Coulson: Solar and Terestrial Radiation (Methods andMeasurements) Academic Press, Inc. New York (1975) 
5. Report of the WMO meeting of experts on UV-B measurements, data quality and standardization of UV Indices. Les Diaberetes, WMO report no. 95 (1995).

6. Report of the WMO meeting of experts on UV-B measurements, data quality and standardization of UV Indices. Les Diaberetes, WMO report no. 127 (1997).

7. Gidelines for site qualityt control of UV monitoring. WMO Report no. 126.

8. Enviromental effects of ozone depletion: 1998. Assessment. UNEP (1998).

9. Z. Mijatović, Lj. Čonkić, S. Miljković: UV zračenje, izvori, osobine, efekti i zaštita, PMF Novi Sad (2002).

10. Jarvis, P.G., 1976: The interpretation of the variations in leaf water potential and stomatal conductance found in canopies in the field. Philos. Trans. Roy. Soc. London. Ser B., 273, 593610 .

11. Jones, H.G., 1983: Plants and microclimate. A quantitative approach to environmental plant physiology. The Cambridge University Press, Cambridge, London, New York, New Rochelle, Melbourne, Sydney.

12. Kreith, F., 1973: Principles of heat transfer. International Text Book Company, Scranton, Pennsylvania.

13. Kirkhan, D., and W.L. Powers, 1972: Advanced soil physics. Wiley and Sons, New York, London, Sydney, Toronto, 534 pp.

14. Leyton, L., 1975: Fluid behaviour in biological systems. Clarendon Press, Oxford.

15. Mihailović, D.T., 1996: Description of a Land-Air Parameterization Scheme (LAPS). Global Planetary Changes, 13, 207-215.

16. Mihailović, D.T., and Jeftić, 1994: An efficient but simple biophysical scheme UNICOS for use in different scale modeling. Environ. Soft., 9, 47-60.

17. Mihailović, D.T., and G. Kallos, 1997: A sensitivity study of a coupled soil-vegetation boundary-layer scheme for use in atmospheric modeling. Boundary-Layer Meteorol., 82, 283315. 
18. Millar, C.E., L.M. Turk, and H.D. Foth, 1965: Fundamentals of soil science. John Wiley and Sons, Inc., New York, London, Sydney, $491 \mathrm{pp}$.

19. Monteith, J.L., 1973: Principles of environmental physics. Edward Arnold, London, 118 pp.

20. Monteith, J.L., 1975: Vegetation and the atmosphere, vol II, Principles. Academy Press, London.

21. Report of the WMO-WHO Meeting of Experts on Standardization of UV Indices and their Dissemination to the Public (Les Diablerets, Switzerland, 21-24 July 1997)

22. UV-Index for the Public, A guide for publication and interpretation of the solar UV Index forcasts for the public prepared by the Working Group 4 of the COST-713 Action (UVB) 
PROF. DR. SCI SULEJMAN KENDIĆ, PHD, DOC. DR.SCI.ADEM SALIHAGIĆ, SENIOR LECTURER

\section{ULTRA-VIOLET (UV) RADIATION AS A NEGATIVE HEALTH INDEX}

\section{SUMMARY}

Radiation whose origin is the Sun includes visible light, heat and UV radiation. UV radiation covers wavelenght area between 100$400 \mathrm{~nm}$ and is divided in 3 groups:UVA(315-400nm9;uvb(280$315 \mathrm{~nm})$; UVC(100-280nm).

As Sunrays pass through the Earth's atmosphere, entire UVC and almost 90 percent of UVB radiation are absorbed by ozone, steam, oxygen and carbon dioxide. Earth's atmosphere has little effect on UVA rays, and because of this fact UV-rays that reach Earths surface contain large quantities of UVA and a smaller amount of UVB rays.

Sun's radiation is an important natural factor because it creates Earth's climate and has a significant influence on the entire enviroment. Ultra-violet part of the Sun's spectre has a very important role in numerous processes in biosphere. UV radiation has several useful effects, but it can also be very hazardous if it transcends defined safety levels. If the amount of UV rays is high enough, self protection ability of certain biological entities becomes weakened and thus these organisms can be severely damaged. This also relates to human organism, especially to the hair and the eyes.

New measure has been introduced in order to avoid side effects caused by exposure to UV rays. It is called UV index and its fundamental function is to alert people regarding the degree of UV radiation's damaging effect and to provide means for undertaking adequate security measures.

UV radiation in the 21. century: learn how to control your exposure to UV rays by using own experience and professional advice, adjust your exposure to UV radiation by considering alteration of UV index values, learn how to undertake adequate security 
measures and educate younger generations how to use them if you are traveling to areas with different types of climate.

Excessive exposure to the Sun and hazardous UV rays have been considered for years as one of the main causes for the development of skin cancer, as well as other diseases. Global warming, holes in the ozone and intensification of Suns radiation also contribute to the forming of skin lesions. 
أ.د. سليمان كانديتش - د. آدم صالح آغيتش الانط الإشعاع فوق البنفسجي (UV) كمعيار سلبي على الصحة

خلاصة البحث

الإشعاع الذي يأتينا من الشمس يضمّ ضوءاً، حرارة والإشعاع فوق البحتف البنسجي. الإشعاع فوق

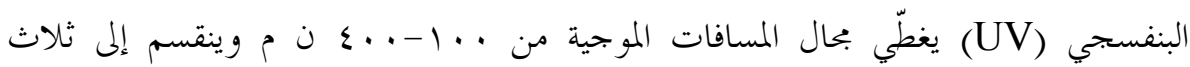

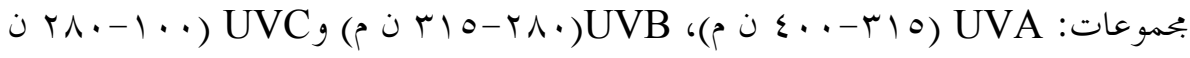

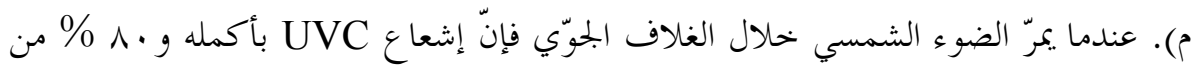

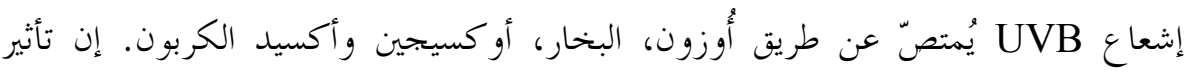

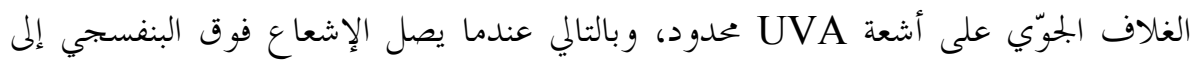

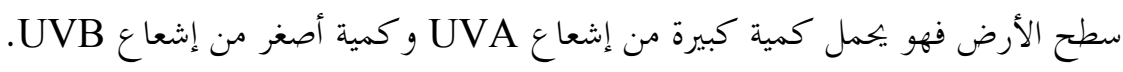

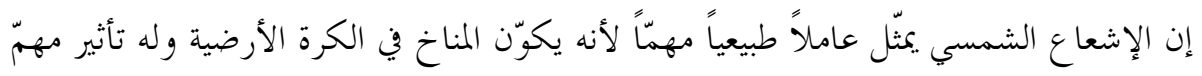

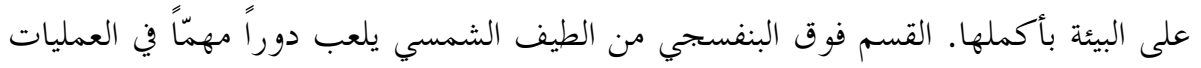

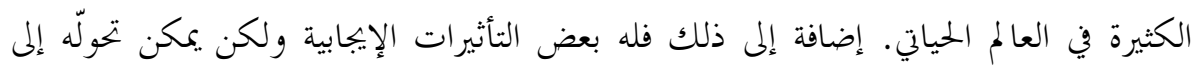

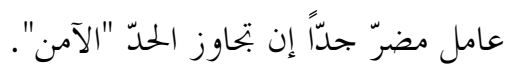

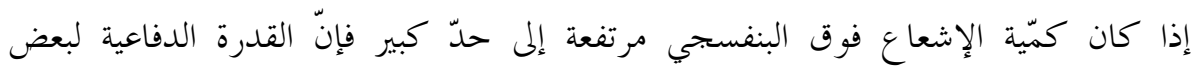

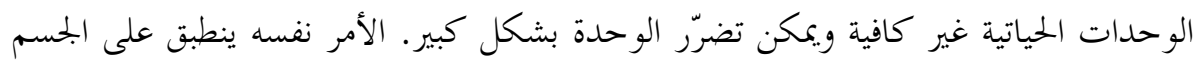

الإنساني، خاصة على الجلد والعيون.

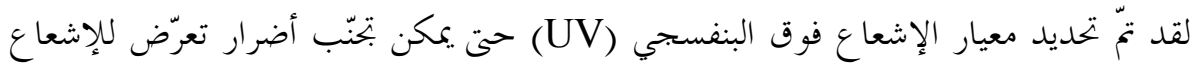

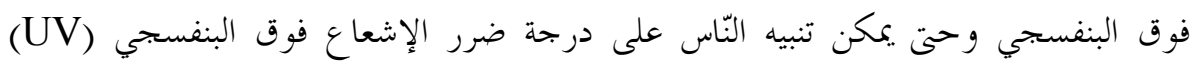

و كيفية التخاذ التدابير الوقائية المعينّة.

الإشعاع فوق البنفسجي (UV) في القرن الحادي والعشرين:

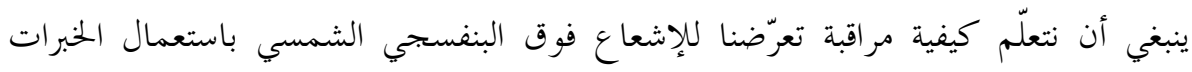

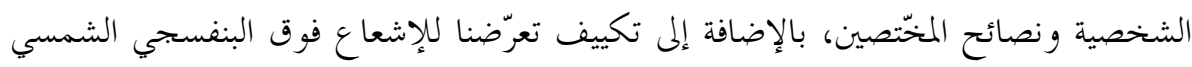

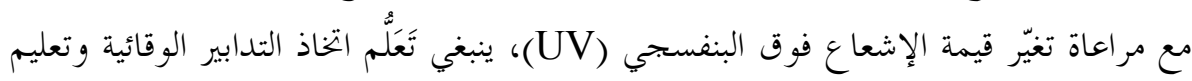

275 
الناشئة كيفية استخدامها في حال السفر إلى المناطق ذات المناخ المختلف حتّ نعمل على تكييف التصرّفات في الشمس بالنسبة إلى الأحوال المناخية الجديدة.

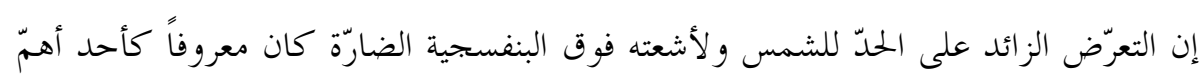

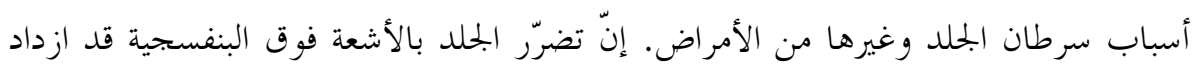

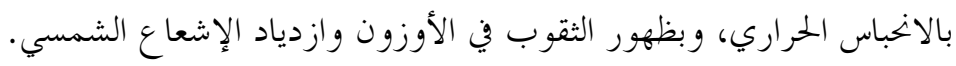

